\title{
Pengembangan desain produk berbahan baku limbah kerang di Bantul
}

\author{
Nor Jayadi, ${ }^{1 *}$ Rahmawan Dwi Prasetya ${ }^{1}$ \\ ${ }^{1}$ Program Studi Desain Produk, Institut Seni Indonesia Yogyakarta, Indonesia
}

\begin{abstract}
The problem that is often faced for small and medium industries is the limited capital they have. They feel unable to hire designers to produce innovative products. They also often objected to allocating funds to conduct design experiments that required a lot of funds that they found to be highly speculative. Many small and medium industries that are comfortable with their conditions, accept orders whose designs come from direct buyers. They only become producers who often have low bargaining positions in the presence of buyers. The price of production is even determined by non-producer buyers. As a result, despite the large number of orders, the welfare of business actors and employees is difficult to improve. UMKM Development Activities This art is done to overcome these obstacles. Pembina who is a lecturer in Product Design Study Program ISI Yogyakarta has the competence to carry out the product innovation development activities. Through a more collaborative activities between lecturers and business actors, some design products produced from clam waste, some of which are made of prototype. With these activities, it is expected that business actors are motivated to continuously make design innovations on the products it produces. Collaboration, for lecturers also have a positive impact, namely the development of insight into the material and engineering workmanship in the field which in turn can be used as learning materials on campus.
\end{abstract}

Keywords: waste, clame, product design

\begin{abstract}
Abstrak
Persoalan yang sering dihadapi bagi industri kecil menengah adalah keterbatasan modal yang mereka miliki. Mereka merasa tidak mampu untuk mempekerjakan desainer agar dapat menghasilkan produk-produk yang selalu inovatif. Mereka juga seringkali keberatan mengalokasikan dana untuk melakukan eksperimen-eksperimen desain yang membutuhkan banyak dana yang menurut mereka sangat spekulatif. Banyak industri kecil menengah yang sudah nyaman dengan kondisinya masingmasing, menerima order yang desainnya berasal dari buyer langsung. Mereka hanya menjadi produsen yang acapkali memiliki posisi tawar rendah di hadapan buyer. Harga produksinya bahkan ditentukan oleh buyer bukan produsen. Akibatnya, sekalipun ordernya banyak, tetapi kesejahteraan pelaku usaha dan karyawannya sulit untuk meningkat. Kegiatan Pembinaan UMKM Seni ini dilakukan untuk mengatasi kendala tersebut. Pembina yang merupakan dosen di Program Studi Desain Produk ISI Yogyakarta memiliki kompetensi untuk melaksanakan kegiatan pengembangan inovasi produk tersebut. Melalui kegiatan yang lebih bersifat kolaboratif antara dosen dan pelaku usaha tersebut, dihasilkan beberapa desain produk berbahan baku limbah kerang yang sebagian diantaranya dibuat prototipe-nya. Dengan kegiatan tersebut, diharapkan pelaku usaha termotivasi untuk secara kontinyu melakukan inovasi-inovasi desain pada produk-produk yang dihasilkannya. Kolaborasi tersebut, bagi dosen juga memiliki impact positif, yaitu berkembangnya wawasan tentang material dan teknik pengerjaan di lapangan yang pada gilirannya dapat dijadikan sebagai materi pembelajaran di kampus.
\end{abstract}

Kata kunci: limbah, kerang, desain produk

\section{Pendahuluan}

Kerang Wijaya adalah Usaha Mikro Kecil dan Menengah dalam bidang pembuatan produk-produk berbahan dasar limbah kerang. Sepintas terlihat aneh karena UMKM (Usaha Mikro, Kecil, dan Menengah) tersebut berada di bagian tengah Bantul, tepatnya di Dusun Watugedug, Kelurahan Guwosari, Kecamatan Pajangan yang wilayahnya $100 \%$ berupa daerah yang berbukit sampai bergunung. Padahal kerang yang digunakan sebagai bahan dasar produknya biasanya berasal dari daerah pantai. Meskipun pantai di wilayah

\footnotetext{
* Koresponden penulis e-mail : norjayadi75@gmail.com
} 
Daerah Istimewa Yogyakarta memiliki panjang sekitar 110 kilometer (Giyanto, 2014), namun ternyata bahan limbah kerang tersebut diperoleh dari pantai utara Jawa. Ketersediaan bahan dasar kerang jenis Simping (Placuna placenta) tersebut cukup berlimpah sebab meski belum menjadi komoditi yang dibudidayakan, namun sangat mudah ditemui dan ditangkap di wilayah pantai utara Jawa, seperti di Kabupaten Kendal, Kabupaten Batang, Kabupaten Pekalongan, Kabupaten Pemalang, Kabupaten Tegal dan Kabupaten Brebes (Prasetya, 2010).

Beberapa penelitian tentang produk berbahan dasar limbah kerang tersebut pernah dilakukan di beberapa tempat di Indonesia (I. M. D. Pratama \& Bendesa, 2015; M. Y. Pratama \& Mutmainah, 2015). Baik dari sudut pandang desain maupun nilai ekonomisnya. Pengembangan desainpun telah banyak dilakukan (Hariyadi, Asyiah, \& Fatahillah, 2013; Hastuti, Arifin, \& Subagya, 2011; Sari, Rismana, Suseno, Tyas, \& Lailassalami, 2013). Namun biasanya dilakukan di kota-kota pesisir dan masih menggunakan pendekatan handmade dan tradisional.

Kerang Wijaya yang didirikan oleh Agus Hartono pada tahun 2009 tersebut memproduksi alat-alat rumah tangga (piring, nampan, tatakan, asbak, lampu meja, bathset, dan lain-lain), furnitur (stool, meja, kursi, drawer, dan lain-lain), dan elemen estetis seperti patung, pigura, dan lain-lain. Media bantunya kebanyakan berupa resin. Saat ini, karyawan yang bekerja di UMKM tersebut berjumlah 9 orang, tetapi bersifat fleksibel sesuai dengan banyaknya pesanan yang dikerjakan. UMKM Kerang Wijaya juga bekerja sama dengan beberapa plasma UMKM sejenis di sekitarnya, sehingga pesanan sebanyak berapapun dapat dikerjakannya. Pesanan yang dikerjakan hampir semuanya berasal dari luar negeri, seperti Spanyol, India, Eropa, dan Amerika.

Produk-produk yang dihasilkan oleh UMKM Kerang Wijaya sudah cukup variatif namun cenderung sama dengan UMKM sejenis di daerah lain. Tidak ada karakter produk khusus yang membedakannya dari produk lain. Selain itu, desain produk yang dihasilkan selama ini berasal dari buyer, sehingga kreativitas produsen dibatasi. Implikasi dari hal tersebut adalah rendahnya bargaining position produsen terhadap buyer, tidak saja terkait dengan harga tetapi juga desain yang ditawarkan. Tujuan kegiatan ini adalah untuk membantu UMKM Kerang Wijaya mengembangkan bisnisnya melalui pengembangan desain yang lebih inovatif sebagai upaya diferensiasi produk yang dihasilkan UMKM sejenis. Selain itu, program ini juga bertujuan untuk memotivasi pelaku usaha untuk selalu mengembangkan produknya melalui inovasi desain secara berkesinambungan.
Kegiatan ini diharapkan memiliki manfaat tidak saja bagi penulis (dosen Program Studi Desain Produk ISI Yogyakarta), tetapi juga bagi mitra (UMKM Kerang Wijaya, Pemerintah Daerah Bantul, dan ISI Yogyakarta. Kegiatan ini dapat menstimulasi kreativitas pelaku UMKM Kerang Wijaya untuk lebih jauh lagi melakukan pengembangan desain yang inovatif sehingga dapat memberikan nilai tambah bagi produk-produknya dibandingkan dengan kompetitor pada usaha sejenis. Bagi Pemerintah Kabupaten Bantul, program kegiatan ini membantu meningkatkan kemampuan UMKM di wilayahnya untuk mengembangkan diri dan berkompetisi, sehingga secara tidak langsung akan berdampak pada meningkatnya kesejahteraan masyarakat di wilayah Bantul.

ISI Yogyakarta adalah perguruan tinggi seni yang berada di wilayah Bantul. Sudah selayaknyalah ia memberikan manfaatnya bagi lingkungan dimana ia berada. Oleh karena itu, kegiatan ini merupakan salah satu bentuk nyata peran serta ISI Yogyakarta untuk ikut berpartisipasi membangun Kota Bantul dengan kemampuan yang dimilikinya di bidang seni, khususnya desain produk. Bagi dosen sendiri, kegiatan ini dapat digunakan sebagai sarana untuk mengembangkan diri dalam rangka meningkatkan kualitas pengajaran bidang yang diampunya. Kegiatan ini memungkinkan dosen untuk berkomunikasi, berdiskusi, dan bertukar pikiran dengan praktisi dan pelaku usaha di bidang desain produk, sehingga muncul wawasan baru yang lebih update yang layak untuk di-share kepada mahasiswa sebagai bentuk pengembangan materi perkuliahan.

Salah satu solusi untuk mengatasi permasalahan di atas adalah dengan melakukan upaya pengembangan desain yang lebih inovatif dan berbeda dengan produkproduk sejenis di pasaran. Solusi tersebut dilakukan dengan mengadakan pendampingan pengembangan desain melalui kegiatan terstruktur yang dijadwalkan berlangsung selama 12 kali pertemuan dari tanggal 11 Oktober hingga 30 November 2016. Peserta yang dilibatkan dalam kegiatan tersebut adalah karyawan UMKM Kerang Wijaya dan cluster usaha sejenis di sekitarnya yang berjumlah 6 orang. Kegiatan direncanakan akan diselenggarakan di workshop Kerang Wijaya, namun bersifat tentatif dan fleksibel, artinya tidak tertutup kemungkinan dilakukan di tempat lain yang lebih representatif. Materi kegiatan juga bersifat tentatif, menyesuaikan dengan kemampuan yang dimiliki oleh para peserta.

\section{Bahan dan Metode}

Peserta yang dilibatkan dalam kegiatan tersebut adalah karyawan UMKM Kerang Wijaya dan cluster 
usaha sejenis di sekitarnya yang berjumlah 6 orang. Pelaksanaan kegiatan diselenggarakan di workshop/bengkel kerja UMKM Kerang Wijaya, di Desa Watugedug RT 02, Guwosari, Kecamatan Pajangan, Kabupaten Bantul. Karena adanya kendala teknis, pelaksanaan kegiatan yang rencananya berlangsung pada dari tanggal 11 Oktober 2016 hingga 25 November 2016, berubah menjadi 1 - 30 November 2016. Pelaksanaan kegiatan ditandai dengan acara Penerjunan Dosen Pembina UMKM Seni ke wilayah kerja di mana UMKM berada.

Materi pembinaan diawali dengan brainstorming untuk mendapatkan gambaran riil kondisi dan situasi yang dihadapi oleh UMKM. Tahap ini juga digunakan untuk mencari peluang-peluang solusi. Langkah berikutnya adalah menyusun brief desain berdasarkan hasil brainstorming tersebut, yang kemudian dilanjutkan dengan pembuatan pembahasan tentang thematic design. Dalam pembahasan tentang thematic design tersebut, diselipkan pula wawasan tentang prinsip-prinsip desain. Ada 7 prinsip desain menurut Francis DK Ching (Ching, 1996), yaitu Proporsi, Skala, Keseimbangan, Keserasian, Kesatuan dan Keberagaman, Ritme, dan Penekanan (tone).

Proporsi merupakan prinsip desain yang menghubungkan suatu bagian dengan bagian yang lain atau kepada keseluruhan atau antara suatu benda dengan benda yang lain. Proporsi berkaitan dengan ukuran, dapat berupa jarak, jumlah/kuantitas, maupun derajat. Suatu objek yang menjadi bagian dari sebuah komposisi tidak dapat dilepaskan begitu saja dari komposisi itu. Ketidakhadirannya dalam komposisi tersebut mempengaruhi komposisi visual secara keseluruhan. Demikian pula, kehadirannya yang tidak memperhatikan proporsinya menjadikan komposisi itu menjadi rusak, menjadi tidak proporsional. Proporsi merupakan salah satu pertimbangan visual yang penting. Dalam kaitan tersebut, perbedaan dimensi relatif yang mencolok pada suatu objek adalah penting. Proporsi akan tampak benar pada situasi tertentu jika kita merasakan bahwa elemen-elemen atau karakteristik yang ada tidak terlalu sedikit atau terlalu banyak.

Skala juga merupakan salah satu prinsip desain yang berhubungan dengan ukuran. Perbedaannya adalah jika proporsi berbicara tentang perbandingan suatu objek terhadap objek lain atau lingkungannya, maka skala berbicara tentang hubungan ukuran suatu benda terhadap ukuran standar yang sudah diakui/dikenal konstan. Ada 3 jenis skala yang dikenal sebagai patokan, yaitu: skala manusia (skala yang mengacu pada standar ukuran manusia), skala visual (skala yang mengacu pada kebesaran sesuatu yang tampak dipunyai jika diukur terhadap benda-benda di sekelilingnya), dan skala mekanik (skala atau perhitungan dari ukuran fisikal sesuai dengan suatu sistem standar pengukuran).

Keseimbangan yang dimaksud adalah keseimbangan secara visual, yaitu suatu keadaan yang sama bobot di antara kekuatan-kekuatan visual yang diproyeksikan oleh elemen-elemen suatu komposisi. Ada 3 jenis keseimbangan yang seringkali digunakan sebagai acuan, yaitu keseimbangan simetris (atau aksial/bilateral, yaitu hasil dari penataan elemenelemen yang identik, punya kesamaan dalam raut, ukuran, posisi relatif pada satu garis lurus atau aksis), keseimbangan radial (hasil penataan elemen-elemen di sekitar satu titik pusat sehingga menghasilkan suatu komposisi yang terpusat), dan keseimbangan asimetris (kesenjangan hubungan dalam hal ukuran, raut, warna, atau posisi relatif di antara elemen-elemen suatu komposisi).

Keselarasan dapat didefinisikan sebagai suatu persesuaian atau kecocokan yang pas dari bagianbagian atau kombinasi bagian-bagian di dalam suatu komposisi. Prinsip keselarasan melibatkan pemilihan elemen-elemen dengan cermat yang memiliki ciri atau karakteristik umum yang sama, seperti raut, warna, tektur, atau bahan. Sekalipun demikian, keselarasan atau harmoni tersebut jika diterapkan terlalu jauh pada pemakaian elemen-elemen dengan ciri yang sama akan dapat menghasilkan komposisi yang tidak menarik, meskipun tetap menyatu. Untuk itu diperlukan kecermatan dan "tegangan artistik" antara keteraturan dan ketidakaturan serta antara kesatuan dan keragaman yang menghidupkan keselarasan sekaligus menciptakan daya tarik di dalam suatu setting komposisi.

Dalam menciptakan suatu komposisi desain, prinsip kesatuan sangat mutlak diperlukan. Tujuan pertama dari pengaturan suatu komposisi adalah kesatuan. Kemudian, di dalam mengembangkan komposisi yang telah menyatu tersebut, untuk mencapai keseimbangan dan keselarasan, perlu dihadirkan elemen-elemen dan karakteristik-karakteristik yang tidak sama, sehingga menimbulkan unsur keragaman dalam komposisi tersebut.

Prinsip irama didasarkan pada pengulangan elemenelemen atau karakteristik-karakteristik yang sama dalam suatu komposisi. Elemen-elemen tersebut diterapkan berulang-ulang untuk kontinuitas dan memiliki ciri yang sama. Kadang-kadang juga bervariasi dalam hal raut, detil, warna, atau tekstur. 


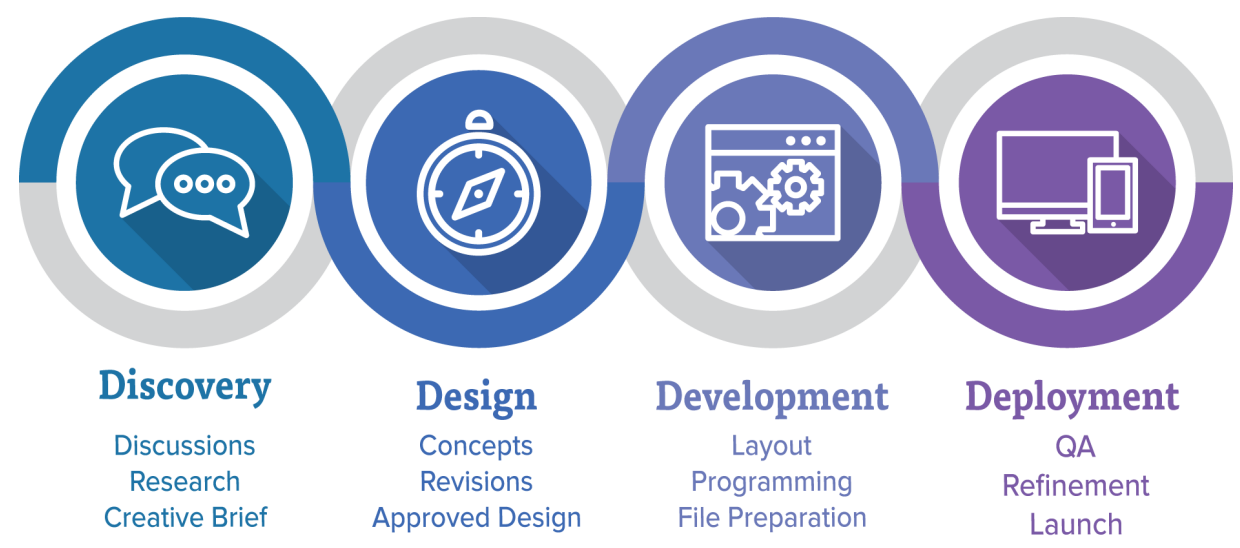

Gambar 1. Proses Desain

Sumber: https://www.hotdesign.com/marketing/the-scott-design-process/

Variasi-variasi ini, baik halus maupun nyata, menciptakan daya tarik visual dan dapat menghasilkan derajat kompleksitas yang lain.

Prinsip tekanan diterapkan dengan penggunaan elemen-elemen dominan dan sub-ordinat dalam suatu komposisi. Suatu desain tanpa suatu elemen dominan akan menjadi lemah dan datar. Sekalipun demikian, jika terlalu banyak elemen-elemen yang tegas, desain tersebut akan kusut dan kacau, menurunkan nilai halhal yang mungkin benar-benar penting. Suatu elemen yang penting dapat diberi tekanan visual dengan cara mendukungnya dengan ukuran yang nyata, raut yang unik, value warna, atau tektur yang kontras.

Setelah membahas teori tentang prinsip desain, pertemuan selanjutnya membahas tentang proses dan metodologi desain. Setelah mendapatkan design brief, melakukan riset pada fase discovery yang diiringi dengan diskusi, maka fase berikutnya adalah membuat desain. Aktivitas dalam fase desain ini adalah menyusun konsep desain, revisi desain, hingga menentukan desain terpilih dari alternatif-alternatif desain yang dibuat. Fase berikutnya adalah fase pengembangan desain (design development). Dalam fase ini desainer melakukan aktivitas programming. Dalam beberapa literatur, riset hingga desain jadi termasuk dalam aktivitas programming. Namun dalam Gambar 1, tampak bahwa programming berada dalam fase development artinya tekanan atau fokus berbeda, dalam hal ini lebih menekankan pada penyusunan atau pendokumentasian dari seluruh proses desain sehingga membentuk rangkaian proses yang mudah dipahami. Termasuk membuat dan menyusun dokumen teknis seperti gambar kerja, detail, spesifikasi, dan lain-lain. Pada fase terakhir, prototipe dibuat dan dilakukan tes/uji kualitas (QA/Quality Assurance) dan perbaikanperbaikan produk atau penyempurnaan prototipe. Jika semua sudah tidak ada masalah, maka dilakukan aktivitas launch atau peluncuran produk ke tengah masyarakat.

Pembahasan tentang proses desain yang lebih bersifat teoritis tersebut kemudian diikuti dengan mengaplikasikannya melalui kegiatan praktik. Praktik pertama adalah pembuatan sketsa desain. Dalam brief design telah diputuskan kegiatan ini akan menghasilkan 2 jenis produk, yaitu furnitur (meja) dan home accessories (hotel tea set). Oleh karenanya, kegiatan pembuatan sketsa desain difokuskan pada 2 jenis produk tersebut.

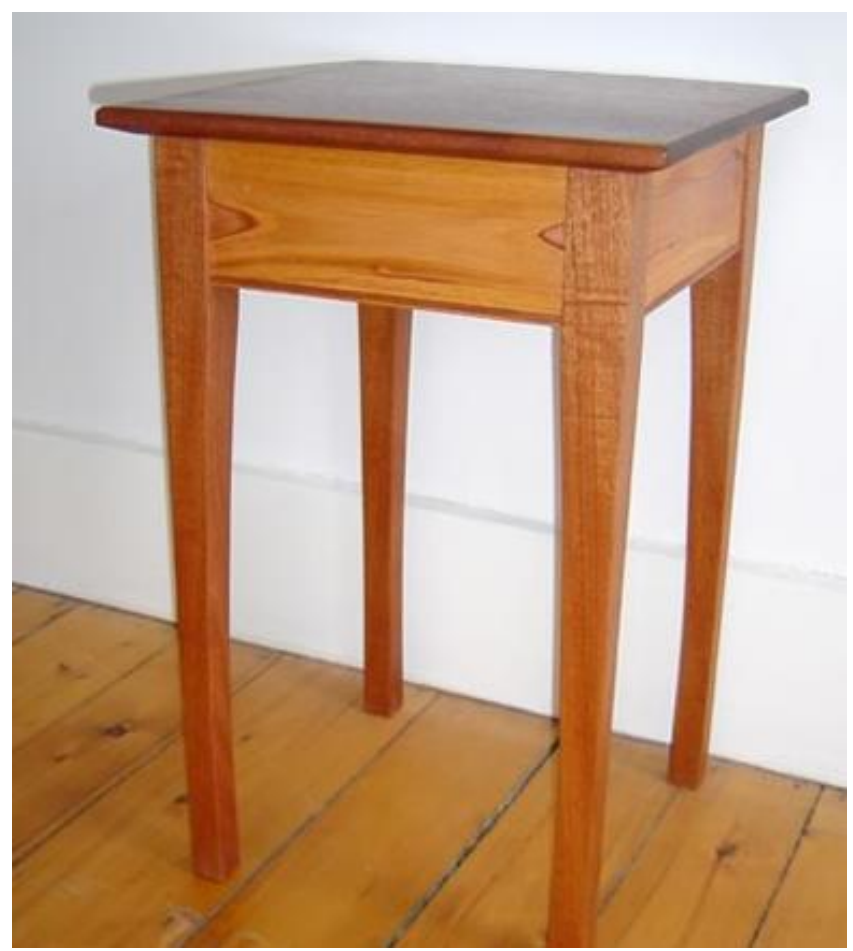

Gambar 2. Image desain Coffe Table 
dapat bekerja. Model tes, masing-masing, aspek visual dan aspek fungsional.

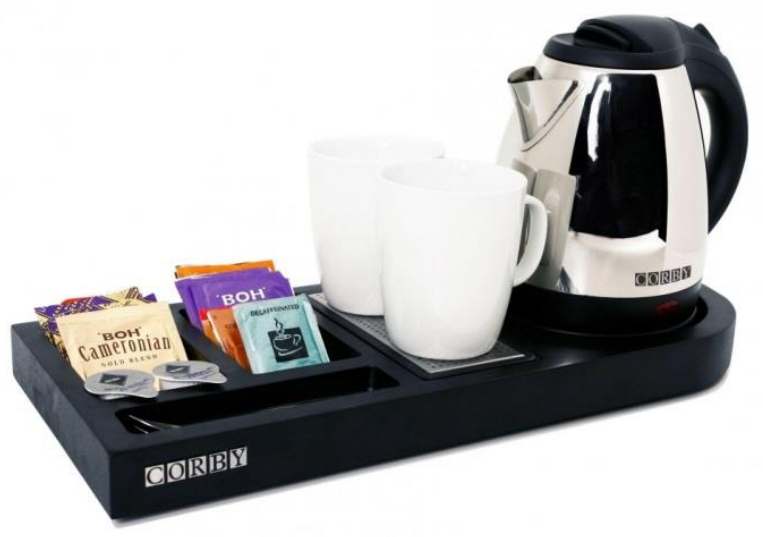

Gambar 4. Image desain hotel tea set Sumber: https://www.corbyofwindsor.com

Maket (Maquettes) adalah sebuah replika tiga dimensi yang skalatis dari desain yang memungkinkan orang untuk mendapatkan gambaran tentang itu dalam kaitannya dengan pengaturan atau lokasi. Sebuah maket dapat diibaratkan sebagai sebuah gambar desain yang hidup. Maket sering digunakan dalam bidang arsitektur untuk memberikan gambaran tentang bangunan akan terlihat seperti dalam konteks lokasi. Dummy adalah mock up berskala penuh yang diproduksi menggunakan material yang telah ditentukan. Tujuan dibuatnya dummy adalah untuk menguji seberapa baik material yang digunakan dan memberikan indikasi unsur taktil (tekstur) dari produk fisik tersebut. Dalam dummy, fungsi utama produk seringkali justru diabaikan karena tujuannya memang untuk mendapatkan gambaran tentang material dan proporsi nyata produk tersebut.

Semua metode prototipe menggunakan skala sebagai bagian integral dari pendekatan pengujian. Maquettes biasanya menggunakan skala untuk mengurangi desain besar menjadi sesuatu yang sederhana untuk dicerna; model bisa skala yang sebenarnya, skala berkurang atau bahkan skala yang diperbesar untuk memberikan representasi yang dapat diandalkan dari desain; boneka printer diproduksi skala penuh; dan ide-ide poster juga dapat prototype pada skala penuh untuk melihat apakah mereka berkomunikasi dengan baik di kejauhan. Dalam kegiatan ini, prototipe desain terpilih (meja dan hotel tea set) dibuat dengan skala 1:1, dengan material riil yang telah ditentukan, yaitu kayu solid dan limbah kerang simping. 


\section{Hasil dan pembahasan}

Mengingat bahwa sasaran kegiatan (UMKM Kerang Wijaya) adalah lembaga bisnis yang seringkali harus mengejar target pembuatan produk pesanan, maka metode yang digunakan bersifat lebih cair dan fleksibel, menyesuaikan dengan kondisi dan situasi di lapangan. Agar tidak berkesan menggurui, metode pendekatan yang digunakan lebih kepada metode diskusi dengan mengemukakan berbagai sudut pandang.

Hasilnya adalah kesamaan visi atau pandangan terhadap pengembangan desain yang semestinya selalu dilakukan secara kontinyu dan berkesinambungan. Selain diskusi, metode presentasi secara sederhana membantu komunikasi antara desainer dan tim. Semua peserta diberi kesempatan untuk menjadi desainer dan mempresentasikannya secara sederhana di depan tim. Komunikasi berupa masukan, apresiasi dan kritik membuat desain yang mereka presentasikan menjadi lebih berbobot.

Kendala yang dihadapi terutama adalah masalah waktu. Kesibukan kedua belah pihak, antara pembina dan yang dibina, antara dosen dan pengusaha/karyawan UMKM Kerang Wijaya menjadi kendala yang utama dalam pelaksanaan kegiatan ini. Sekalipun jadwal kegiatan telah disepakati bersama, namun dalam realisasinya tidak dengan mudah dilaksanakannya. Sekalipun demikian, kendala tersebut dapat diatasi dengan me-reschedule tatap muka dengan waktu yang lebih fleksibel, sehingga kedua belah pihak tidak terganggu dengan pelaksanaan kegiatan ini.

Dalam proses pelaksanaan, muncul beberapa hal yang menjadi pertimbangan dalam melakukan inovasi desain produk kerang di UMKM Kerang Wijaya. Diantaranya adalah rutinitas order dengan desain yang sama dalam jumlah besar. Rutinitas ini membuat pihak pengelola enggan untuk melakukan inovasi desain yang menyita waktunya. Faktor berikutnya adalah besarnya biaya untuk membuat inovasi dari mulai proses desain hingga prototipe. Sebagai sebuah kegiatan bisnis, biaya yang dikeluarkan untuk itu tentunya harus diperhitungkan untuk menentukan harga jual produk tersebut. Seringkali pengelola merasa tidak sepadan dengan hasil yang diperolehnya. Faktor yang terakhir yang membuat enggan melakukan inovasi desain adalah maraknya kegiatan penjiplakan desain. Produk inovatif yang dihasilkan melalui proses desain yang memakan waktu, pikiran, dan biaya, dengan tanpa beban dan dalam waktu singkat dijiplak oleh produsen lain, bahkan dengan harga produk yang lebih murah karena tidak memperhitungkan biaya proses desain.
Tetapi dengan memotivasi dan memberikan gambaran-gambaran perlunya melakukan inovasi desain, pengelola UMKM Kerang Wijaya antusias untuk mengikuti program kegiatan Pembinaan UMKM Seni dari ISI Yogyakarta ini. Beberapa tahapan kegiatan telah disampaikan di atas, dari mulai brainstorming hingga pembuatan prototipe. Mengingat waktu pelaksanaan yang pendek dan ketersediaan dana yang terbatas, maka hanya ada 5 desain dan 2 prototipe yang dihasilkan.

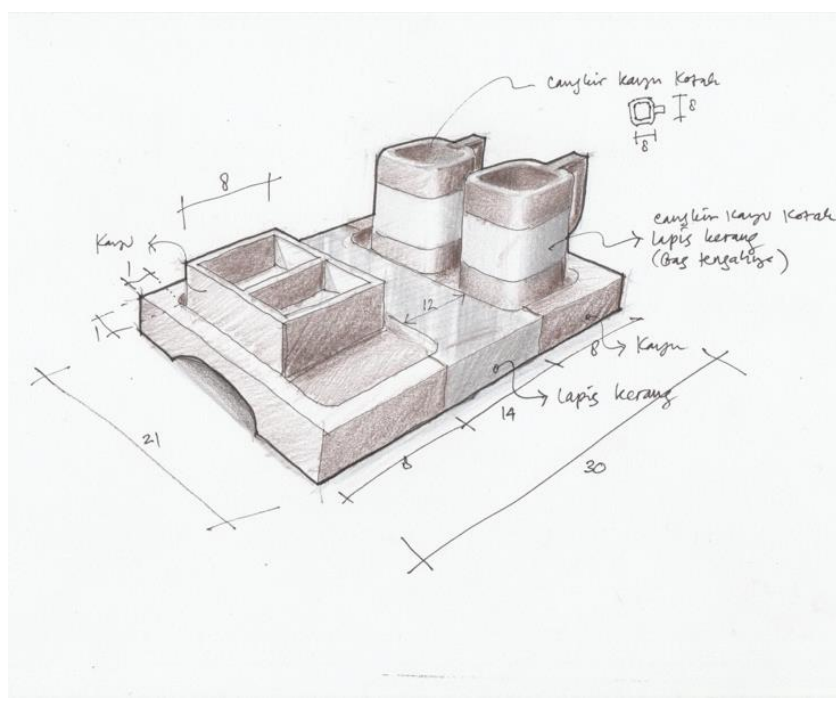

Gambar 5. Sketsa desain produk hotel tea set (Desain oleh Rahmawan)

Keterbatasan dana sejujurnya menimbulkan kekhawatiran terhadap adanya potensi membengkaknya anggaran yang sudah direncanakan. Hal ini terjadi mengingat inovasi desain yang dikerjakan seringkali membutuhkan eksperimen material dan konstruksi yang sulit diduga anggarannya. Bahkan potensi kegagalan mewujudkan desain ke dalam bentuk prototipe seringkali dinilai cukup besar yang beresiko pada membengkaknya anggaran yang disediakan. Oleh karena itu, demi menghindari agar hal tersebut tidak terjadi, maka inovasi desain yang dilakukan terpaksa dibatasi pada inovasi hanya pada aspek bentuk saja. Sedangkan eksperimen material dan konstruksi sebisa mungkin dihindari. Inovasi bentuk tetap mengacu pada teknik-teknik produksi yang sudah sering digunakan.

\section{Kesimpulan}

Pembinaan UMKM Seni di UMKM Kerang Wijaya dalam bentuk pengembangan desain produk berbahan kerang berhasil dilaksanakan dengan lancar dan sesuai dengan harapan seperti direncanakan pada awal 
kegiatan. Inovasi desain produk berbahan baku limbah kerang terlaksana melalui kolaborasi antara pembina (dosen Program Studi Desain Produk) dengan pelaku usaha produk berbahan baku kerang (pemilik dan karyawan UMKM Kerang Wijaya, serta pelaku usaha cluster produk sejenis di Desa Guwosari, Pajangan, Bantul.

Inovasi desain dengan mengacu pada teori dan prinsip desain serta memperhatikan design trend forcast 2016-2017 dipadu dengan pengetahuan material dan teknik produksi yang telah dikuasai oleh pelaku UMKM menghasilkan desain-desain produk berbahan kerang yang inovatif dan memiliki nilai jual tinggi.

Inovasi desain hanyalah salah satu solusi bagi persoalan-persoalan yang dihadapi oleh UMKM Kerang Wijaya dan UMKM sejenis di wilayah Desa Guwosari, Pajangan, Bantul. Perlu ada programprogram kegiatan lain yang dilakukan untuk meningkatkan kualitas produk tersebut. Diantaranya adalah perlunya branding baik untuk pasar domestik maupun pasar internasional.

\section{Daftar pustaka}

Ambrose, G., \& Harris, P. (2010). Design Thinking. Lausanne: AVA Publishing SA.

Ching, F. D. (1996). Ilustrasi Desain Interior. Jakarta: Penerbit Erlangga.

Giyanto, A. (2014). Panjang Pantai 110 Kilometer, DIY Potensial Kembangkan Produksi Garam. Jurnal Maritim Online, (Desember). Retrieved from http://jurnalmaritim.com/2014/12/panjang-pantai110-kilometer-diy-potensial-kembangkanproduksi-garam/

Hariyadi, S., Asyiah, I. N., \& Fatahillah, A. (2013). Pelatihan desain kerajinan kerang pada pengrajin kerang di Kabupaten Situbondo. Jember: Universitas Jember, Tidak Diterbitkan.

Hastuti, L. S. S., Arifin, A., \& Subagya. (2011). Pengembangan Desain Produk Seni Kerajinan Kerang Simping. Dinamika Kerajinan Dan Batik, 29(Juni), 37-42.

Prasetya, J. D. (2010). Potensi Kerang Simping di Kabupaten Brebes Jawa Tengah. In Prosiding Seminar Nasional Hasil Perikanan dan Kelautan Jurusan Perikanan Fakultas Pertanian Universitas Gajahmada 2010.

Pratama, I. M. D., \& Bendesa, I. K. . (2015). Analisis Faktor-Faktor yang Mempengaruhi Nilai Ekspor Kerajinan Kerang di Provinsi Bali. Jurnal Ekonomi Pembangunan Universitas Udayana, 4(4), 313325. 
Pratama, M. Y., \& Mutmainah, S. (2015). Nilai Estetika Kerajinan Cangkang Kerang UD. Baru Senang (Halik Mawardi), Panarukan, Situbondo. Jurnal Pendidikan Seni Rupa, 3(1), 11-19.

Sari, E. D. T., Rismana, A. D., Suseno, Tyas, C. A., \& Lailassalami, U. (2013). Program Kreativitas Mahasiswa Pemanfaatan Kerang Laut untuk Usaha Souvenir. Semarang: Fakultas Ilmu Komputer, Universitas Dian Nuswatoro, Tidak diterbitkan. 